\title{
Ethnologies
}

\section{Paths of Speech}

\section{Symbols, Sociality and Subjectivity among the Muinane of the Colombian Amazon}

\section{Carlos David Londoño Sulkin}

Volume 25, numéro 2, 2003

Language and Culture / Langue et culture

URI : https://id.erudit.org/iderudit/008053ar

DOI : https://doi.org/10.7202/008053ar

Aller au sommaire du numéro

\section{Éditeur(s)}

Association Canadienne d'Ethnologie et de Folklore

ISSN

1481-5974 (imprimé)

1708-0401 (numérique)

Découvrir la revue

Citer cet article

Londoño Sulkin, C. (2003). Paths of Speech: Symbols, Sociality and Subjectivity among the Muinane of the Colombian Amazon. Ethnologies, 25(2), 173-194.

https://doi.org/10.7202/008053ar

\section{Résumé de l'article}

Les Muinane, groupe indigène de la Colombie amazonienne, décrivent la subjectivité individuelle comme provenant soit des substances cultivées qui constituent le corps des êtres humains, soit des substances sauvages qui usurpent le rôle des bonnes substances. La subjectivité morale, en particulier, provient du tabac, de la coca et d'autres substances partagées par une communauté. Dans une telle narration, la subjectivité est à la fois individuelle et collective, d'origine divine aussi bien qu'animale. Le discours des Muinane semble parfois présenter la subjectivité comme radicalement déterminée par des entités extra-individuelles. L'auteur affirme, cependant, que la conscience du soi entre en grande partie dans leurs narrations de l'action - c'est-à-dire qu'ils comprennent leurs propres actions comme étant orientées vers soi autant que vers autrui et que, de plus, leur manière de parler de leurs propres interactions sociales ainsi que de leurs pensées/émotions confèrent une forme à celles-ci. L'auteur met l'accent sur l'aboutissement de la vie sociale et sur le caractère intrinsèquement social du soi, en évitant de mettre en exergue une culture monolithique qui déterminerait de manière unidirectionnelle la subjectivité et la sociabilité.
Ce document est protégé par la loi sur le droit d'auteur. L'utilisation des services d'Érudit (y compris la reproduction) est assujettie à sa politique d'utilisation que vous pouvez consulter en ligne.

https://apropos.erudit.org/fr/usagers/politique-dutilisation/ 


\section{PATHS OF SPEECH}

Symbols, Sociality and Subjectivity among the Muinane of the Colombian Amazon

\section{Carlos David Londoño Sulkin \\ University of Regina}

\section{Symbolic Webs, Public Space and Individual Consciousness}

In this essay I will contribute to ongoing academic conversations (Butler 1993; Cohen 1994; Rapport and Overing 2000; Rosaldo 1984; Taylor 1985; Sahlins 1985; Parkin 1982; Volosinov 1986 [1973]) on the relationship between social structure and individual agency by discussing Muinane people's ${ }^{1}$ discursive and ritual practices concerning their own subjectivity in general, and certain institutionalized forms of relationships in particular. The pertinence of this discussion is twofold: it will explore how Muinane people themselves speak about and thereby theorize the relationship between "society", "individuals" and "selfhood," and it will suggest how individuals' discourses and other symbolic deployments linked to these theories partly constitute their own subjectivities and social relationships.

The theoretical scaffolding that made Muinane people's insightful use of their theories of selfhood and sociality salient to me is Charles Taylor's (1985) account of human agency and language. In particular, I am persuaded by his claim that human agents are partly constituted by their understandings (and misunderstandings) of themselves. Taylor states that "our self-understanding essentially incorporates our seeing ourselves against a background of [...] distinctions between things which

1. I lived in Muinane communities for eighteen months between 1993 and 1998 as part of my research. Muinane people consider themselves one of the "People of the Center", along with the Uitoto, Miraña, Bora, Nonuya, Andoque and Okaina people, all indigenous to the Caquetá-Putumayo region of the Colombian Amazon. 
are recognised as of categorical or unconditioned or higher importance or worth, and things which lack this or are of lesser value" (1985: 3). This background of distinctions is articulated in language, and in fact can be a feature only of reflexive, language-endowed beings. An example of such a background distinction is the Muinane's contrastive valuation of the capacity to remain tranquil in personal adversity, and of violent intemperance. This opposition is a defining aspect of the kind of beings humans can be. Persons' actions are often only intelligible to observers with considerable knowledge of actors' self-interpretations and the background distinctions that articulate them.

The background distinctions of individuals' self-interpretations are constituted, to a great extent, by socially available associations of linguistic and other symbolic elements, acquired and deployed in individuals' unique histories. Selfhood is therefore intimately linked with the social interactions that make these symbols available to individuals, creating what Charles Taylor calls "public space" - a common vantage point from which participants in dialogic exchanges survey the world together (1985: 259)2 . Public space (of intimacy, mutual distrust, reverent respect, or other) is achieved dialogically, through the participants' continuous iterations of symbols that constitute attempts at creating it, and through the reaffirming, equally creative responses to these symbols. These symbols must be citations of symbols from other, similar contexts, if they are felicitously to create a public space. ${ }^{3}$ They must to some extent be citations of previously witnessed expressions.

2. A common vantage point does not necessarily imply a "good" or altruistic relationship. Exchanges of furious insults also establish public space and create footings on the basis of symbols. Furthermore, a "commonality of viewpoint" could involve as little as the participants' dialogically achieved sense that at least some of the symbols deployed are being used in a familiar or recognisable way.

3. Austin (1975) used the adjective "felicitous" to refer to effective performative utterances. People's symbolic deployments sometimes manage to create public space "as intended". However, as symbols they are subject to infelicities of various kinds and can fail to establish an intended or even intelligible public space. For example, a person produces a "friendly" gesture, assuming some intimacy with his or her interlocutor, and the interlocutor reacts to it rather as a manifestation of outrageous cheekiness. In this case, the speakers' expectations and perceptions of the footings of their relationship differ; if the interaction continues, the new public space created may be one in which both understand that one of them is peeved and the other embarrassed. 
Two closely related points I wish to make in this essay are that social life and individuals' understandings of themselves are processual achievements, dependent on dialogical deployments of symbols, and that anthropological accounts of social life should attend to individual consciousness, because it is individuals who actually iterate symbolic forms, and because their actions vis-à-vis one another depend on their (symbolically constituted) understandings of themselves (see Cohen 1994; Cohen and Rapport 1995: 4). Here, I will use Muinane material to make a case for an "anthropology of consciousness".

As I shall discuss below, some Muinane people's accounts of their own subjectivity could be seen as positing a view of subjects as absolutely constrained to think, feel and behave according to the demands of their statuses and roles vis-à-vis one another, following predetermined scripts of either "divine" or "social" origin. Muinane customs would thus seem to converge with the Kwakiutl's and Zuñi's as discussed by Mauss (1985), and with the Fox's as discussed by Gearing (via Cohen 1994: 1): they would seem to regard their behaviour as inhering in the social roles in which they are placed. Mauss's essay suggests that the Kwakiutl and Pueblo had not developed a view of persons as possessing an essential or abstract self underlying the "masks" or the accoutrements of social life. Who a person was and how he or she behaved was accounted for in terms of a role in "sacred dramas" of existence (Mauss 1985: 12). For Mauss, the Kwakiutl and Pueblo were defined entirely by their roles. Absent from his account of these people was the self that made choices on the basis of an understanding of itself as an agent.

In contrast to Mauss's assertions about Kwakiutl and Pueblo peoples, I suggest Muinane people avoid the opposition between socially constrained, rule-bound subjectivity and autonomous, "free" individual agency, by positing a material source of thoughts, emotions and actions that is in itself both social and individual (see Belaunde 2000). I suggest that Muinane individuals manifestly make insightful use of this theory in accounting for their own subjectivity, or in other words, that a notion of subjectivity and indeed of consciousness of the self is central to Muinane people's accounts of action. I propose that individuals' iterations of elements of this theory are constitutive of their subjectivity and of their social life. However, this theory of subjectivity and social life is not monolithic or monologic; different persons use it to frame events differently and draw different implications from them, and some in fact seem to set it aside altogether and make use of altogether different "theories". 


\section{A Theory of Selfhood and Sociality}

Muinane cosmological rhetoric, quotidian prescriptions, and critical evaluations of their own and others' actions often express interlinked postulates of what it is to be a human being and how proper human beings think and act; what I perceive as a morality-centred theory that addresses issues of sociality, livelihood, subjectivity, embodiment, agency, identity, and aesthetics.

Several of my informants referred to a proper social life as "living well" or "living pleasurably", and stated that such states were a precondition and result of the successful reproduction of the community or kinship group. They also spoke of the reproduction of society in terms akin to our notion of "progress", and presented it as what should be the ultimate purpose in life. My understanding is that for Muinane people, only Real People (a deictic term that, depending on the speaker's perspective, refers to the Muinane, to People of the Centre, to Indigenous peoples, or to humanity in general) ${ }^{4}$ can live properly in community, and through community living achieve the combined purpose of living pleasurably and multiplying.

A Real Person's thoughts/emotions (which are inextricably linked together and hence glossed as such) are indissolubly commingled in the Muinane term ésámaje, which are the "Speeches" of substances that the person has consumed (such as manioc, chillies, herbs, coca, and most especially, tobacco) and/or out of which the person has been manufactured by his/her kin. They are of divine origin, and have agencies of their own. By way of example, informants in the Middle Caquetá region explained to me how, much like a tape recorder that can only produce sound when a tape is inside it, human beings can only speak with tobacco inside them. Following a similar line of reasoning, a Muinane man once explained to me that when his wife worked hard to produce food to nourish her people, her thoughts/emotions were "the Speech of Cool Herbs" in her.

In this scheme, people have thoughts/emotions and the capacity to speak because their very bodies are made out of agency-endowing substances. In the first place, the semen that constitutes each embryonic person is in itself a form of tobacco paste; it is the highly purified product of each man's body processing the substances he consumes. Conversely,

4. This "true humanity" excludes animals, who nonetheless share some "human" features with Real People (Viveiros de Castro 1998: 471). 
tobacco paste is said to be the sweat-cum-semen of the creator deity, the Grandfather of Tobacco. Second, people consume food, tobacco paste and other substances throughout their lifetimes, and these things come to constitute both their flesh and their subjectivities.

In many of the accounts of Muinane, each "true" human being is described as the product of an intentional, collective process of manufacture. Hence the large number of counsels concerning the provision and consumption of food and ritual substances (e.g., what mothers and fathers should nourish their children with, how the latter should consume it, what they should avoid, and so forth). The substances consumed and the ways in which they are consumed may affect not only the bodies and competences of the consumers themselves, but also those of their future children and other kin. Poor eating may cause malformation of the body, making it inadequate for demanding physical labour. The abuse of some substances may lead to the production of semen that will engender weakly or vice-ridden children (see Londoño Sulkin 2002: 243). A poor or undisciplined diet may also lead to poor performances in another child-shaping task: baby kneading. Newborn children should be massaged by a kinswoman so that they grow up to be well shaped; a poorly "dieted" kinswoman will misshape a child she kneads (see Lagrou 2000 and Londoño Sulkin 2000).

An important ritual in the manufacturing of proper human beings is the Watering, whereby an elder performatively ${ }^{5}$ consigns in the child's body the gender-specific features and the virtues that the child will need in order to be a competent human being. Without undergoing a proper "manufacturing process", a human being may look and even appear to act as a proper human being, but will eventually fail somehow in the complex task of achieving both individual humanity and proper human sociality.

These and other rituals tend to involve the use of food and ritual substances. People of one patriline ${ }^{6}$ are supposed to be made out of the same substances, and to some extent by the same people endowed with agency stemming from the same substances; in short, kin are

5. "Performatively" here is meant in Butler's sense of "divine performativity" (1993: 12-13), where it is by the power of the speaker's will that the referent of an expression comes to be.

6. The Muinane's kinship system, though cognatic, has a strong patrilineal bias with salient social organizational implications. 
consubstantial. Sharing such substances, in Muinane people's rhetoric, entails similar thoughts/emotions, similar inclinations, and in fact, mutual love. The latter, according to one of my Muinane friends, is the result of one's lineage's tobacco paste, made from the lineage's single strain of tobacco plants, recognising itself in another person's body.

Properly made people, with competent bodies and truly human thoughts/emotions, are by definition inclined towards the sustenance of tranquil, lovingly concerned, generous interactions with co-residents, and are furthermore physically and intellectually/emotionally equipped for the production of new generations of proper substances and proper new human beings. In this account, good social relationships are an essential condition for achieving all that is desirable in life.

The substantial origin of bodies and of thoughts/emotions also explains the possibility of disease and the disruption of social life. Muinane cosmogonic myths tell of how the Creator attempted several times to make Real People. The first generations were animals that were shaped like humans. The Creator provided them with prescriptions and prohibitions, and with the tobacco that endowed them with the subjectivity and agencies necessary to achieve the proper lifestyle he prescribed. Yet they failed to follow the Creator's counsel: they cannibalized each other, they were incestuous or frantically oversexed, they were lazy, they were careless, they overslept. They corrupted their tobacco, which thenceforth was to be their own and a source of their perverted subjectivity. The infuriated Creator transformed them into their animal shapes and condemned them to be food for human beings, or otherwise their victims. Therefore animals envy, fear and hate human beings, and seek to subvert human life by placing their foul tobaccos and other spurious substances in human beings, causing the latter bodily disabilities, or perverting their subjectivities. As a result people sometimes behave in animalistic, antisocial fashions, leading in turn to their inability to interact in a manner leading to a pleasurable, productive, fertile lifestyle. Taken to extremes, animal intervention could lead to the absolute incapacity of people to reproduce, and to their immersion in an antisocial chaos of uncontrolled sorcery (see Belaunde 2000; Santos-Granero 2000).

Muinane people often say, when trying to explain their own and other people's experiences and interactions, that substances "said" things or "warned them" (or failed to warn them) of bad things to come. 
Amancio, one of my Muinane friends and an important source of information, once provided me with an interesting account of this matter. He stated that unlike the proper tobacco, the Speech of the Jaguar inside a person does not say "my brother". From his explanation of this, I gathered that one of the things tobacco did was to say inside the person "This is my brother [or sister]", constituting the person's awareness of the nature of the relationship with the other when in the presence of a sibling. As a consequence of this awareness the person would address and treat the other appropriately: with loving concern, with proper avoidance of any sexual proximity, and so on. Animalistic tobaccos, on the other hand, would create a different, immoral kind of subjectivity: it would not say "This is my brother," nor generate appropriate thoughts/emotions and actions.

Juan, my host in one Muinane community, provided me with yet another interesting detail concerning subjectivity and tobacco. I asked him what the feeling of shame was, and he quickly responded that the tobacco inside a person would realise that an impropriety, a mistake, had been committed, and would lower its head in shame. This is an example of rhetoric that could be understood as a native theory of "structural" determinism: thoughts/emotions and interactions with kin would normally be absolutely determined by a substance of social and divine origin that provides sociable subjectivities specific to each institutionalized or named kind of relationship (see Londoño Sulkin 2001b: 294).

The link that the Muinane's rhetoric posits between consubstantiality and intersubjectivity does not make claims to personal autonomy and agency unintelligible, or even rare ${ }^{7}$. They frequently pointed out to me that they did not know what another person was thinking, and in fact that nobody could know (except perhaps in an omniscient hallucinogenic trance). They were also very insistent that individuals make their own decisions, and that no one can make decisions for another. I remember Juan telling me of a counsel elders were supposed to give to youths: the latter were not to assume that others' successful endeavours constituted a reason to follow those same instructions. Tobacco gave instructions and warnings to each person, according to their particular conditions and circumstances.

7. See Overing (1993: 207-208) for a similar argument. 
On several occasions, I witnessed Muinane individuals stating that "one is merely a Real Person," in discussions stressing human fallibility in contrast to the axiomatic moral infallibility of tobacco. This alternate conception of Real Personhood would seem to be closer to a "naturalist" view of selfhood, where there would be an essential, individual ego. Pace Bloch (1977), however, this way of speaking of persons cannot be placed in a theoretical context of everyday, practical, commonsensical conversation as opposed to ritual contexts. It is a part of everyday talk, which is often ritual talk. Like the other version of Real Personhood, the salient point about this one is its morally evaluative content. The contrast lies in that the "weak" Real Person in these accounts would be prone to immoral temptations and misbehaviours, and would be incapable of proper behaviour, whereas in the "strong" Real Person true humanity is axiomatically moral.

\section{The Agency of Speeches and Substances}

The materiality of moral thoughts/emotions and properly shaped bodies and of their corrupt counterparts, and the subjectivity of the bearers of these materials, are central to the Muinane's understanding of their own agency. This agency for the most part involves the capacity to manipulate substances or their bearers either materially or socially. This capacity stems from substances such as tobacco paste, coca, hot chillies, water, herbs and others, which are agents in their own right, endowed with their own intentionality. Many of the manipulations in question are conceived as predatory transformations that involve dealing out death. Tobacco is perhaps the most important source of such predatory agency. It is in itself a powerful predator, and in constituting people's bodies it provides them with some of its predatory capabilities. Furthermore, people use what I call "instrumental Speeches" to direct the agency of the tobacco that they consume so that it preys upon evil agents and their substances, and thereby transforms them with some people-making or community-making purpose (see Londoño Sulkin 2000 and 2001b, as well as Overing and Passes 2000).

Instrumental speeches are more or less formulaic utterances, which the mambeadores (adult men who consume mambe, a powdered coca leaf preparation) understand to act in different ways to change some aspect of the world. My interlocutors made different claims about them: that they were the very Speech of the Creator deity sounding directly through the speaker; or that they were "recordings" (conscience- 
constituting citations, in a sense) of the Creator's words; or that they directed the attention of the creator deity to some transformation which people wanted him (or her, depending on the clan telling the story) to carry out. Alternatively the spoken utterances themselves were deemed to be powerful, or somehow to harness the agency of substances (see also Tambiah 1968: 183).

Most significant endeavours among Muinane make some use of another of this transformative, predatory agency (Echeverri 2000; Londoño Sulkin 2000 and 2001b; Overing and Passes 2000). Food and ritual substance preparations are often understood to be filtering or purifying processes in which some agent - water, fire, or some other subjectivity-endowed substance or object - kills, destroys or otherwise does away with pathogens in the original stuff, leaving only a purified, desirable essence. The felling and burning of the forest to make a garden is performatively treated in the Speech of Felling as a human war against trees, or alternatively as a meal in which the deities of tobacco, axes and fire all "eat" evil trees, transforming them into fertile ashes from which desirable substances will grow. Speeches of Healing dealing with disease usually involve the use of tobacco paste and coca, understood in the first place to be the source and power of knowledge, and then to be predators that transform the evil substances affecting the sick and place them again in the animals that originated them. These animals then become easy prey for people. Finally, the building of a maloca (a traditional ceremonial and residential longhouse) involves numerous transformations of diseases and negative affects into elements of the house, and the "domestication" of evil agents such as the great trees that become house pillars or drums. Transformed into a house by the Speech of Maloca Construction, these elements become protective guardians that ensure the health and fertility of the inhabitants of the maloca.

\section{The Collective Achievement of a Proper Social Life}

To deal with the threats of evil agents, to produce the abundant foodstuffs and ritual substances needed to live well, and to set up the conditions for the successful procreation of the kinship group, people must carry out a variety of daily and occasional tasks and rituals. Muinane people strongly emphasize that to do so effectively they depend on the complementary endeavours of men and women, and on the mutual support among spouses, siblings, siblings-in-law, children, in 
laws and "Men of the Speech of Tobacco". They also stress in their abstract accounts that people have to relate with others in such a way that they awaken their good will and desire to help.

The circumstances to which Muinane people attribute the greatest need for support are the great transformative rituals of building a maloca and holding the dance rituals that legitimate the maloca's existence. According to the rhetoric, proper human life could not continue without malocas and dances. It is through these great transformative rituals that maloca owners ensure the procreation and well-being of their people, which include all the participants in the rituals. Maloca owners depend heavily on the support of these very people to carry out their rituals.

There are different categories of people among the participants in a dance ritual. There are jáhemina or híijahooto ["insiders" or "people of the maloca"] and jitikávo, who are referred to in Spanish as los ayudantes, "the helpers". The precise definitions of which consanguineal kin and which affines fit into these categories varies between malocas, but both categories of people have the moral obligation of collaborating with the maloca owner and his wife in the preparation of the ritual by working hard on the necessary tasks and by providing substances. Another crucial category of participants in rituals is that of the maloca owner's Men of the Speech of Tobacco. These are indispensable ritual interlocutors from other patrilines.

To summon people to a dance ritual, its "owner" must send his Man of the Speech of Tobacco an ímogaibi, a package of tobacco paste. The latter in turn must redistribute it among his kin to recruit them as másiminaha "singers", the singing, dancing, game-bringing guests for the maloca owner's ritual. According to the rhetoric, if the man who holds a dance ritual "speaks truly" (i.e., is knowledgeable and moral), the tobacco he prepares and sends to guests in the f́mogaibi illuminates the Man of the Speech of Tobacco as to the causes of all kinds of tribulations their kin and other close relatives may suffer: their improper thoughts/ emotions, diseases and other problems. That very tobacco then hunts down the faunal origin of the tribulations, or transforms their substances into animals. Then the next day or soon after, it places the guilty beasts in the path of the hunting guests, so that the latter may kill them. The guests present these dead beasts, which are evil agents transformed into nourishing flesh, to the dance owner. Before being consumed, the dead carcasses may need further "cooling" transformations by whipping their pathogenic tobacco out of them, or using Speeches to transform their 
potentially harmful flesh into nominal vegetable matter. In short, through the ritual the substances of evil and tribulations are transformed into desirable stuffs for the benefit of a proper social life (Londoño Sulkin 2000 and 2001b).

Muinane people often make explicit their awareness that one of the threats of situations of social conflict or trouble is the dampening of the willingness of people to support each other through substances, dialogue and physical labour. Similarly, they often insist that badtempered or otherwise unpleasant people lose the good will of others. In such situations, they ask, "whom can you ask for help if your child is sick, or if your tasks are too great?"

\section{limaji and the Path of Speech}

A specific field of endeavour in which mutual dependence is a salient feature is that of dialogue, or Iímaji. This is an agglutinated term, composed of the root iima- (talk, converse) and of the classificatory suffix -ji-, which in one sense can be glossed "speech, discourse, mouth or language", and in another, clearly differentiated sense, as "path".

My Muinane interlocutors were explicit in claiming Iímaji to be an integral part of different kinds of relationships. My friend Juan's use of the term and his explanations of it provided me with some understanding of its complexity. One of its referents is the specialized form of dialogue of the men's nightly rituals, which is different from other speech genres in that it is very rhythmic and slightly melodic. When used in this sense, Iímaji refers to instrumental Speeches. These are understood to be powerful instruments that bring about the effects they name (healing, cooling, killing, and others) as long as they are deployed in a dialogue between moral interlocutors (see Candre and Echeverri 1996). A key image that Muinane people use often to exemplify this requirement is that of two men, father and son, or brothers, or Men of the Speech of Tobacco, holding Iímaji to heal the sick. They remind each other of important and necessary parts of the stories and formulae that make up the Speeches, and reaffirm, encourage and "give music" to each other's utterances. Without such interlocution, a man's Speeches would have little if any agency to heal; he would forget to deploy important formulae or to mention significant mythical events, or else whatever elements of the Speeches he could remember simply would not work. 
Juan pointed out to me that rocks lacked the Speech of Conversation, and therefore always remained the same, without growing or multiplying. Similarly, some of the animals in the Speeches of Apprising (i.e., myths) differed from human beings precisely in their inability to converse properly: oropendolas spoke simultaneously, parrots mimicked others' Speeches, and yet other birds interrupted each other, spoke too quickly or too slowly, did not listen, became angry or simply ran out of Speech, and so on. Because they had no proper Iímaji they lacked the capacity to achieve a moral lifestyle ${ }^{8}$.

The term Í́maji may be used as well to refer more generally to the established possibility of communicating intelligibly with someone. In this sense, having Ímaji with another means on the one hand that one knows how to address him or her, understands the language, knows how, when and where to say things, and so on, and on the other hand, that there is some established precedent of interlocution. Ímaji is thus, in this sense, an agential "knowing the ropes" of an institutionalized form of social interaction. For instance, Juan claimed he lacked Íímaji with white men because he had not gone to school and therefore did not know how to speak Spanish well or how to behave properly at a meeting of white men. ${ }^{9}$

Both senses of the term seem to be important in references to the "Path of the Speech of Conversation" [Íímaji júhai]. This term is a metonym for the established relationship of interlocution between two men whom I could loosely describe as "friends" or "ceremonial allies". The image of a Path of Speech, however, is most often and saliently used in talk about the Path of the Speech of Tobacco.

The Path of the Speech of Tobacco encompasses more than discourse, including the geographical space to be traversed in one direction by a traveller taking a specially prepared package of tobacco

8. The fact that animals do reproduce does not constitute counter-evidence against the indispensability of dialogue, for Muinane people; Amancio noted that animals reproduced "any old way": improperly, incestuously, miserably.

9. Tomás Román, the Uitoto president of a regional political organization called CRIMA, jokingly noted these differences in formalities: he stated that among white men, it was polite for one to speak in public standing up, and impolite to do so with one's mouth full. Among Indians, he said, it was the reverse: it was impolite to speak without a mouthful of coca powder, and one should be sitting down in the coca circle to speak seriously. 
paste from one lineage's maloca leader to his Man of the Speech of Tobacco in order to demand the other's help in some ritual endeavour, and in the other direction by the latter and his followers making their way to the ritual in response to the "summons of tobacco". In the rhetoric, however, it is clear that "path" also refers to numerous aspects of the social relationship between the Men of the Speech of Tobacco. For instance, before embarking on the path of the Speech of Tobacco, the Men of the Speech of Tobacco discuss for what purposes they will use the path, who will actually physically transport the tobacco summons in the ritual host's name, when he will deliver the summons, and how the Men of the Speech of Tobacco to be summoned will receive the tobacco. The "path" between such men, and therefore between lineages of different clans, also involves prescriptions and prohibitions concerning how all involved will behave when visiting the other lineage's maloca, and when receiving guests at their own, as well as certain considerations of the kinds of Speeches which the men linked by it can deploy together, and furthermore, their thoughts/emotions regarding each other.

Men of the Speech of Tobacco are supposed to inherit from their fathers the responsibility of keeping Paths of Speech of Tobacco between lineages open. Because the rhetoric on subjectivity posits it to stem from substances shared between kinspersons and transmitted from generation to generation, Men of the Speech of Tobacco (as well as men with less glorified relationships of mutual concern and support) could to some extent be supposed to think/feel towards each other what their fathers felt towards each other, and to act accordingly. This could be oversimplified as indicating that Muinane people do not account for behaviour in terms of self-direction (because it is extrinsic substances that do the directing).

The importance of Men of the Speech of Tobacco lies in the fact that any large ritual depends on the added "strength" (the agency, knowledge and active good will) of several such men, who use various Speeches in their own different mambeaderos but with a common set of purposes: to ensure that there is enough food and drink for all in the future, that diseases and other tribulations dawn as game, that it does not rain on the day of the arrival of the guests, that all involved are well counselled concerning proper and improper behaviour, and in general that the ritual is successful. 
Manuel once explained to me that a man who holds a dialogue with his brother in order to keep rain at bay prior to a dance ritual (or to achieve any other moral purpose, for the matter) has limited "strength" (i.e., the agency to achieve his ends) if the pair is alone. However, if the maloca owner's Men of the Speech of Tobacco are doing the same with their own brothers in their own mambeaderos, at the same time as he is, their Speeches unite and gain great strength, to keep dry all the people travelling to the ritual. As he explained this to me, Manuel made wide-sweeping gestures that represented the Speeches travelling across the sky overhead from the different directions of the malocas of his Men of the Speech of Tobacco, and converging in the sky above his own. He stressed the strength and effectiveness of those converging Speeches. On the other hand, a lone mambeador, bereft of support through tragic isolation or because of his own lack of social skills, is condemned to the miserable, relatively infertile existence his unaccompanied Speeches can eke out for him. Hence the importance of a path along which Men of the Speech of Tobacco can travel to request each other's help ${ }^{10}$.

\section{The Muinane's Public Space and Self Consciousness}

On one occasion, I witnessed Ruben bringing prey to his new Man of the Speech of Tobacco, Juan, who had recently sent him a tobacco summons to Juan's forthcoming dance ritual. Ruben approached the maloca singing in his deep, magnificent voice, letting listeners know that a "baby" - a figurative reference to liquid tobacco prepared for the dance ritual - had been crying from hunger, but that he had brought the baby some meat. When he walked into the maloca with a dead peccary (wild pig) slung over his shoulders, still singing loudly, the members of the maloca cheered happily. Ruben kept singing, and Juan leapt up and excitedly responded, "He caught it, it was he who caught it!" while indicating the tobacco pot. Juan was thereby claiming that his tobacco (part of which he had sent out as a summons, part of which he kept for the dance ritual itself) had transformed some evil into dead prey. Eventually a young man from the maloca took the peccary from

10. Jürg Gasché, from the CNRS (personal communication), has suggested that in the past, the People of the Center may have constituted chiefdoms in which Men of the Speech of Tobacco controlled the labor and produce of large numbers of kinspeople and affines. 
Ruben, and Ruben and Juan proceeded to hold a ritual dialogue. This dialogue involved an account of the killing of the pig, and Juan's insistence that it was no longer harming human beings. The main event ended when Juan and his wife gave a generous package of foodstuffs and ritual substances as "payment" to Ruben.

I see the singing, the diverse manipulations of the beast's carcass and the pair's dialogue on the agency and moral demands of tobacco as effective symbolic deployments that helped recreate the cosmological context within which they made sense, and the picture of the kinds of beings men can be in that cosmos. In deploying these symbols dialogically, Juan and Ruben furthermore resituated themselves in relation to each other. The fact that Ruben took the peccary to Juan instead of consuming it himself was intelligible in the context of a cosmos in which tobacco preys upon animals. His song and their dialogue made manifest that this was their interpretation. They treated the successful hunt as proof of the "truth" of Juan's Speeches and tobacco, in a way that seemed to take their accounts of the agency of substances for granted. But their symbolic actions did not stem from an inert, monolithic, socially shared worldview independent of particular individuals; they were rather individuals' citations of some of the symbols that articulated that cosmos for them, and also recreations of that cosmos.

Their symbolic deployments placed Ruben and Juan in a special relation to each other; that is, they created a public space between them. The footings of the relationship between them (previously that between nephew and distant classificatory uncle, with its own symbolic repertoire) were changed and enriched by the new symbols they could incorporate into their dialogue. The formal manner in which Juan took tobacco to Ruben, and Ruben's gesture of bringing the peccary, were creative of the new relationship between them.

All the Men of the Speech of Tobacco with whom I talked spoke about themselves and their performances as Men of the Speech of Tobacco in terms of their thoughts/emotions and personal formation as proper human beings. They claimed to be disciplined, discerning, motivated by love and esteem. Often this involved stories of moments in which they had "trembled" in reaction to circumstances that had sorely tempted them to misbehave, but that they had been aware that this unworthy desire was not their own and had been capable of "standing 
firmly" and acting properly. In sending Ruben a tobacco summons, inviting him to renew the "Path of Speech" that had linked their fathers before them and to join him in carrying on with a similar relationship, Juan perceived himself to be complying laudably with esoteric tradition. He was outspoken about this. In turn, others recognized that Ruben's response to the tobacco summons was that of a worthy Man of the Speech of Tobacco. In taking the kill to Juan he made manifest his knowledge and generosity: he had appropriately recognised that the success of the kill reflected the power of Juan's tobacco — for which he was, conversely, an apt recipient - and that his kill was not his own to eat with his wife and children. Ruben and Juan related to each other thus because they understood themselves to be Real Men, endowed with admirable moral knowledge and predatory agency, collaborating and thereby contributing in tangible ways to the health and multiplication of their people.

Some of the details I described above could be understood to indicate that Muinane people account for their behaviours and interactions exclusively in terms of the unoriginal, cited, exogenous thoughts/emotions that are supposed to correspond univocally to social statuses, roles and institutionalized relations. However, their rhetoric clearly makes explicit their self consciousness, and in fact that such consciousness is an important element in their accounts of action. On several occasions I witnessed in which people misbehaved, others told them in Muinane to "look into their bodies", very much in the sense of "know thyself". For them, though, it meant recognising that their thoughts/emotions at that point in time were not really "their own", but rather the perverted subjectivity of a beast or jungle spirit. "Looking into their bodies" involved licking tobacco and consuming coca, which would enable them to "see" what it was that was causing them to think/ feel and act in a certain inhuman way.

I have little doubt Muinane can and do use such rhetoric and follow "proper" ritual formulae without "meaning" it, much like people sometimes pray, kneel and otherwise participate in religious liturgies without believing in their theological content (see Cohen 1994: 19). But the actors who carry out these "theatrical" performances are not essential, unconstructed beings; they still think and plan and evaluate and self-interpret, and they do so through symbols acquired in part in social interaction. My point is that Muinane people's discourses concerning substances, virtues, animals and so on, are very much a 
part of the "background of distinctions" which are constitutive of their self-interpretations. They can come to re-evaluate their own experiences, and be intimately persuaded that these were not truly their own.

The case of Napoleon provides an interesting context for understanding Muinane people's morally evaluative constructions of "self". Napoleon was much criticized by his community and by others for his violence against his wife and for allowing himself to be seduced by a very young woman. At one point he protested publicly that he was not to blame; the blame was his father Roberto's, who as a young man had smoked marijuana and drunken aguardiente (cane alcohol) carelessly. These hot substances of white men had become his father's semen, and out of that semen Napoleon had been made. It was those substances that made him misbehave in the ways he did.

Elsewhere (Londoño Sulkin 2001a; 2001b: 406-408; 2002), I have noted that Napoleon's rejection of his own guilt sounded rather Durkheimian or Maussian, in the limited sense that he posited extrinsic compulsions upon himself as an individual. In a sense, Napoleon actively redeployed public discourses on selfhood to present himself as being strictly constrained to behave according to extra-individual scripts. I do not know how persuaded Napoleon was by his own claims, but in any case they were fully intelligible citations of the narratives of his people. Nonetheless, these narratives do not constitute a monolithic, monologic, unequivocal corpus. Many of his peers scoffed at his demand for sympathetic understanding and contested his denial of culpability. Their evaluations indicated that for them there was an individual bodily locale of accountability for virtuous or flawed action. They could still deem the origin of some behaviour to be a divine or animalistic substance, but at least temporarily, this material subjectivity and the body it settled into and through which it became manifest coalesced into a locatable Real Person, a self who was deserving of praise or needful of healing if not chastisement. The least a Real Person could do would be to "sit firmly", lick tobacco and resist evil thoughts/emotions, or "look into his own body" and request help to get rid of his diseases and evil thoughts/ emotions.

Another interesting difference of opinion surfaced around this event. Napoleon's kin were quick to say that their own tobacco did not cause people to behave in Napoleon's fashion, and so indeed, that Napoleon's actions stemmed from some evil, foreign substance, perhaps even from 
ensorcellment. For them, he was in need of healing. A few members of other clans and ethnic groups, however, framed the event differently. They pointed out to me that Napoleon's clan was all like that: "hot" people, violent and prone to anger. "That is the coca that they mambe," one Uitoto told me, questioning the morality — the proper humanity - of the entire clan.

Parenthetically, I will note one young man's very different take on misbehaviours in general. He did not seem to think of virtuous or flawed behaviour in terms of agential substances, but rather in terms of undesirable personality features, which he called vicios, "vices". For him, Napoleon (and each miscreant he spoke about) was very much his own man, autonomous, and responsible and punishable for his own misbehaviours. For this young man, attempts at explaining misbehaviour in terms of extrinsic agencies seemed to be a travesty, and acceptance of them intolerable leniency.

\section{Conclusion}

Muinane people's notion of "self" is rooted in materiality. Tobacco in several Muinane individuals' accounts was presented as the substantial source of each proper individual's subjectivity. However, the subjectivity it provided was intrinsically social, insofar as it was a divinely established moral subjectivity shared by the proper human beings the tobacco constituted. This subjectivity contrasted with the immoral subjectivity provided by false tobaccos, and shared by those constituted by such tobaccos.

Muinane individuals' reflexively evaluative accounts of their own and others' thoughts/emotions and actions are articulated in cosmological terms. These accounts and evaluations are at least partially constitutive of their subjectivity, and can generate changes in how individuals act and think/feel. Furthermore, Muinane people's dialogical citations of cosmological terms and symbols recreate certain understandings of the cosmos, and create or maintain (that is, re-create) the footings of relationships. More specifically, their articulations of their subjectivities in terms of thoughts/emotions of extrinsic substantial origin, and those actions stemming from such articulations, have enabled them to be on rather unique footings with one another, to relate in very particular Muinane ways. Their citations of terms and symbols additionally made these available anew to themselves and others for 
further citations. However, I have also shown how a common account, a certain set of associated terms and symbols to some extent shared by Muinane people, can be given radically different interpretations by different individuals.

To summarize, I have made a case for understanding both the Muinane's social life and their understandings of themselves as processual achievements, rather than treating individual selves as radically determined by the imposition upon them of a fixed cultural package, or alternatively, treating Muinane society as comprised by the convergence of individual subjectivities constituted independently of social life. As part of stating this case I have also argued that the Muinane's achievement or recreation of both their sociality and individual subjectivities depends on their insightful use of partly shared, symbolically constituted, theories of subjectivity, morality and community life. Attending to their use of symbols therefore implies as well attending to individuals' consciousness. 


\section{References}

Austin, John. L. [1955] 1975. How to do things with words. Oxford: Clarendon Press.

Belaunde, Luisa Elvira. 2000. "The convivial self and the fear of anger amongst the Airo-Pai of Amazonian Peru". In Joanna Overing and Alan Passes, eds., The Anthropology of love and anger: the aesthetics of conviviality in Native Amazonia. London/New York, Routledge: 209-220.

Bloch, Maurice. 1977. "The Past and the Present in the Present". Man, 12 (2): 278-292.

Butler, Judith P. 1993. Bodies that matter: on the discursive limits of "sex". New York: Routledge.

Candre, Hipólito, and Juan Alvaro Echeverri. 1996. Cool tobacco, sweet coca: teachings of an Indian sage from the Colombian Amazon. Devon: Themis.

Cohen, Anthony P. 1994. Self consciousness: an alternative anthropology of identity. London/New York: Routledge.

Cohen, Anthony P. and Nigel Rapport. 1995. "Introduction: Consciousness in anthropology". In Anthony P. Cohen and Nigel Rapport, eds., Questions of consciousness. London/New York, Routledge: 1-18.

Echeverri, Juan Alvaro. 2000. "The first love of a young man: salt and sexual education among the Uitoto Indians of Lowland Colombia". In Joanna Overing and Alan Passes, eds., The Anthropology of love and anger: the aesthetics of conviviality in Native Amazonia. London/ New York, Routledge: 33-45.

Lagrou, Elsje Maria. 2000. "Homesickness and the Cashinahua self: a reflection on the embodied condition of relatedness". In Joanna Overing and Alan Passes, eds., The Anthropology of love and anger: the aesthetics of conviviality in Native Amazonia. London/New York, Routledge: 152-169.

Londoño Sulkin, Carlos David. 2000. “Though it comes as evil, I embrace it as good': social sensibilities and the transformation of malignant agency among the Muinane". In Joanna Overing and Alan Passes, eds., The Anthropology of love and anger: the aesthetics of conviviality in Native Amazonia. London/New York, Routledge: $170-186$.

. 2001a. "El yo y la responsabilidad entre los Muinane de la amazonía colombiana”. Nova \& Vetera, Abril-Junio: 72-85. 
. 2001b. The making of Real People: An interpretation of a moralitycentred theory of sociality, livelihood and selfhood among the Muinane (Colombian Amazon). Ph.D. dissertation, School of Philosophical and Anthropological Studies, University of St. Andrews, Scotland. 2002. "The Narrative Framing of the Self among the Muinane". In Joyce Goggin and Michael Burke, eds., Travelling Concepts II: Meaning, Frame and Metaphor, Amsterdam, ASCA Press: 234-248. Mauss, Marcel. [1938] 1985. "A category of the human mind: the notion of the person; the notion of the self". In Michael Carrithers, Steven Collins and Steven Lukes, eds., The Category of the Person. Cambridge (UK), Cambridge University Press: 1-25.

Overing, Joanna. 1993. "Death and the Loss of Civilized Predation among the Piaroa of Orinoco Basin". L'Homme, 126-128: 191-211 Overing, Joanna, and Alan Passes. 2000. "Introduction: Conviviality and the opening up of Amazonian anthropology". In Joanna Overing and Alan Passes, eds., The Anthropology of love and anger: the aesthetics of conviviality in Native Amazonia. London/New York, Routledge: 64-81.

Parkin, David J. 1982. "Semantic anthropology." A.S.A. monographs 22. London/New York: Academic Press.

Rapport, Nigel, and Joanna Overing. 2000. Social and cultural anthropology: the key concepts. London: Routledge.

Rosaldo, Michelle Zimbalist. 1984. "Toward an anthropology of self and feeling". In Robert Alan LeVine and Richard A. Shweder, eds., Culture theory: essays on mind, self, and emotion. Cambridge (UK)/ New York, Cambridge University Press: 137-157.

Sahlins, Marshall David. 1985. Islands of history. Chicago: University of Chicago Press.

Santos-Granero, Fernando. 2000. "The Sisyphus Syndrome, or the struggle for conviviality in Native Amazonia". In Joanna Overing and Alan Passes, eds., The Anthropology of love and anger: the aesthetics of conviviality in Native Amazonia. London/New York, Routledge: 268-287.

Tambiah, Stanley Jeyaraja. 1968. "The magical power of words." Man, 3 (2): 175-209.

Taylor, Charles. 1985. Human agency and language. Cambridge (UK)/ New York: Cambridge University Press.

Urban, Greg. 1996. "Entextualization, Replication, and Power." In Michael Silverstein and Greg Urban, eds., Natural Histories of Discourse. Chicago, The University of Chicago Press: 21-44. 
Viveiros de Castro, Eduardo Batalha. 1998. "Cosmological deixis and Amerindian perspectivism." Journal of the Royal Anthropological Institute of Great Britain and Ireland, 4 (3): 469-488.

Volosinov, Valentin Nikolaevic. [1973] 1986. Marxism and the Philosophy of Language. Cambridge (MA): Harvard University Press. 